\title{
Oil price shocks and U.S. dollar exchange rates
}

(1)

(1)

(1)
5

Hongtao Chen ${ }^{\mathrm{a}}$, Li Liu ${ }^{\mathrm{b}, \mathrm{c}}$, Yudong Wang ${ }^{\mathrm{d} *}$, Yingming $\mathrm{Zhu}^{\mathrm{d}}$

${ }^{\text {a }}$ School of Economics \& Management, Southeast University, Nanjing China

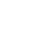
${ }^{\mathrm{b}}$ School of Finance, Nanjing Audit University, Nanjing, China

'Jiangsu key laboratory of financial engineering, Nanjing Audit University, Nanjing,

China

${ }^{\mathrm{d}}$ School of Economics and Management, Nanjing University of Science and Technology, Nanjing, China

*Corresponding author

Corresponding address: XiaoLinwei 200, Xuanwu District, Nanjing, China E-mail: wangyudongnj@ 126.com (Yudong Wang)

Tel: +86 13681663442 (Yudong Wang) 8 19 20

1




\section{Oil price shocks and U.S. dollar exchange rates}

\section{Abstract}

In this paper, we investigate the impacts of oil price shocks on the bilateral exchange rates of the U.S. dollar against currencies in 16 OECD countries. Our empirical findings indicate that the responses of dollar exchange rates to oil price shocks differ greatly depending on whether changes in oil prices are driven by supply or aggregate demand. Oil price shocks (need to say supply or demand shocks here) can explain about $10 \%-20 \%$ of long-term variations in exchange rates. The explanatory ability of oil shocks to exchange rate variations becomes much greater after global financial crisis. Based on parametric and nonparametric tests, we find little evidence of nonlinear relations between oil prices and exchange rates.

Keywords: Oil price shocks; Exchange rates; Impulse response; Nonlinearity; Causality 


\section{Introduction}

Over the last few years, the volatile oil market had caused great concerns among market participants and policy makers. This leads to extensive studies on the impacts of oil price changes on macroeconomy [1-8]. After mid-2014, crude oil prices experienced a large crash due to the increase of global oil production from Saudi Arabia and Russia [9]. During this period, the appreciation of US dollar was also observed. Under this background, one may doubt whether the dollar appreciation was caused by persistent decreases in oil prices. For this motivation, we investigate the effects of oil price changes on dollar exchange rates.

In the empirical literature, there are a plethora number of studies on the relations between oil price and exchange rates, including cointegration relationships, causality behavior, co-movements, information transmission and the usefulness of out-of-sample prediction ${ }^{1}$, and so on. The obtained results are highly inclusive. Different from existing studies, we focus on following four questions:

First, are the relationships between oil price changes and exchange rates linear or nonlinear? This is a basic question but has important implications. For example, if there are nonlinear relationships, the popular VAR models that assume the linear linkages are misspecified and are likely to cause misleading results. Several studies have documented the nonlinear relationships between oil prices and economic variables $[2-3,10-11]$. These studies focus on asymmetric relationships and show that the magnitude of the effects of oil price changes on economic activity is greater when

\footnotetext{
${ }^{1}$ See the detailed literature review in Section 2.
} 
oil prices increase than that when oil prices decrease. Therefore, it is possible that the effects of oil price changes on exchange rates are asymmetric. We first investigate the asymmetric effect using a parametric Wald test based on Hamilton's [12] specification. Moreover, many other forms of nonlinear relationship between oil price and exchange rate such as volatility spillover (second-order comovement) [13-14], tail dependence [15-17], structural break and regime switching [18] have been revealed in the literature. It is very difficult to find out which type of nonlinearity or how many forms of nonlinearity exists in the connections between oil price and exchange rates. Testing all possible forms of nonlinearity is computational demanding. Due to this consideration, we further examine the nonlinear relationships using a nonparametric causality test. This test is to effectively detect nonlinear causality behavior but does not rely on the specification of nonlinear specification. Somewhat surprisingly, we find little evidence of nonlinear causality running from oil price changes to exchange rate changes. The absence of nonlinearity improves the credibility of VAR-based results.

Second, are the responses of exchange rates to different kinds of oil shocks consistent? It is further argued that current models postulate that the effect of an exogenous increase in the price of oil is the same, regardless of which underlying shock in the oil market is responsible for driving the price of crude oil. Recent work by Kilian [5] has shown that the effects of demand and supply shocks in the crude oil market on U.S. macroeconomic aggregates are quite different, depending on whether the oil price increase is driven by oil production shortfalls, by a booming world, or by 
shifts in precautionary demand for crude oil that reflect increased concerns about future oil supply shortfalls. Given that different shocks have different effects on the oil price change, we would expect similar differences in the effect of these shocks on exchange rate. To the best of our knowledge, disentangling the impacts of oil supply and demand shocks on dollar exchange rates separately has not been done in the literature.

In this paper, we address this issue. We follow a structural vector autoregressive regression (VAR) framework proposed by Kilian and Park [19] to decompose oil price changes into oil supply shock, oil demand shock and other oil-specific shocks. Then, we investigate the effects of different oil shocks on the U.S. dollar exchange rates against currencies in 16 OECD countries including large oil-importing and oil-exporting countries in the world over the sample period from January 1990 to December 2014 with monthly observations.

Third, what are the contributions of oil price shocks to exchange rate variations quantitatively? Up to here, we examine the level of exchange rates. In addition, we examine the effect of oil price shocks on variations of exchange rates. This will enhance our understanding of the impact of the shocks not only on the level of exchange rates but also on the volatility of exchange rates. We use variance decomposition technique to find the contribution of oil shocks to variations in exchange rates.

Finally, did oil-exchange rate relationships change after financial crisis? It has been widely accepted that some occasional events can cause the structural changes in 
the linkages of economic variables. In this sense, the explanatory power of different oil supply and demand shocks to exchange rate variations during post-crisis period may be different from that during pre-crisis period. To address this question, we divide the whole sample into two subsamples and investigate the contributions of three oil shocks to exchange rate variations via the variance decomposition method.

We perform a detailed robustness test on our main findings. First, we use an alternative oil price measure and redo empirical analysis. This is motivated by Lee et al. [20] who point out that the effects of oil shocks on the economy during the period when oil price changes are volatile are different from those during the period when oil price changes are relatively stable. Therefore, to a certain extent, the role of the magnitude of oil price change (volatility) in oil price-exchange rate linkages should not be neglected but this issue has not been addressed in the literature of oil price-exchange rate relationships. To fill this gap, following Lee et al. [20], we rescale oil price change by conditional standard deviation implied by generalized autoregressive conditional heteroskedasticity $(\mathrm{GARCH})[21]$ and then do empirical analysis again.

Oil shocks may have impact on exchange rates through affecting other macroeconomic determinants of exchange rates. For example, high oil prices can cause high inflation rates by increasing the industry cost [1]. The Fed may adjust the interest rate as a response of high inflation rates [22-23]. These indirect effects cannot be ruled out according to our four-variable VAR. Due to this consideration, our second robustness analysis is to reinvestigate the oil price-exchange rate relations by 
adding two macroeconomic determinants of bilateral exchange rates of dollar to our main structural VAR framework, the relative inflation and interest rate.

Third, the lag length of a VAR is certainly affect estimation results. Accordingly, we use an alternative structural VAR with different lag lengths. The results from impulse responses confirm the robustness of our core findings.

This paper can be related to some recent papers on similar issues. For example, Kilian et al. [24] estimate the effects of oil supply and demand shocks on several measures of external balances of both oil-important and oil-exporting countries. They conclude that the effects of oil price changes on merchandize trade balance and the current account depend on the source of the shock. We find that their finding also holds for the linkages from oil shocks to exchange rates and therefore is an important complementary of Kilian et al. [24] as current account and exchange rates are closely linked. This paper is also related to Bodenstein et al. [23] who use a DSGE model to show the message that the best central bank policy response to oil price fluctuations depends on why the price of crude oil has changed. We give a plausible explanation for their result using structural VAR and show that oil price changes triggered by various supply and demand shocks have different impacts on exchange rates. Ferraro et al. [25] use oil price changes to predict the exchange rates of CAD/USD. Since the effects of different oil supply and demand shocks on exchange rates are heterogeneous, we can expect that the use of both oil fundamental and price information can obtain more accurate exchange rate forecasts.

The remainder of this paper is organized as follows. Section 2 provides a detailed 
literature review on the relationships between oil prices and exchange rates. Section 3 is the data description and shows some preliminary analysis. Section 4 outlines the methodology. Section 5 shows main empirical results. Section 6 concludes and discusses some implications.

\section{Literature review}

It has been well documented that there is a strong relationship between exchange rates and oil prices, in particular, for the countries whose economy heavily depends on oil as an importing or exporting product. The traditional terms of trade argument suggests that when the price of an importing (exporting) good rises (falls), if the demand for that good is very inelastic, as is the case for oil ${ }^{2}$, this produces deterioration in the trade balance, which decreases the value of the local currency [26-27]. In many studies, terms of trade are commonly approximated by the real oil price [28-29], and these papers have used labels such as "petrocurrency" or "oil currency" to describe the importance of this factor in explaining exchange rate movements.

exchange rate determination is Korhonen and Juurikkala [30] who study a panel of nine OPEC countries. Chaudhuri and Daniel [31] reveal that the nonstationary behavior of US dollar exchange rates is due to nonstationary behavior of oil prices using cointegration and causality tests. In country-specific contexts, Zalduendo [32],

\footnotetext{
${ }^{2}$ For example, Baumeister and Peersman [33] show that both the short-run elasticities of oil supply and of oil demand have declined considerably since the second half of the 1980s. Kilian and Murphy [34] find that the short-term demand elasticity of oil demand is well below unity.
} 
Koranchelian [35], and Mongardini [36] document a key role of the oil price as a trigger of real exchange rate movements in Venezuela, Algeria, and Egypt respectively. Several studies also provide empirical evidence in favor of the Russian Ruble being an oil currency [37-38] (Spatafora and Stavrev, 2003; Oomes and Kalacheva, 2007). Lizardo and Mollick [39] modify the monetary model of exchange rates by adding oil prices and find that oil prices can significantly explain the exchange rates of US dollar against major currencies in some countries such as Canada, Mexico, Russia and Japan.

More recently, Sari et al. [40] find the evidence of a weak long-run relationship among precious metals, oil prices and exchange rates of euro/dollar using cointegration analysis. Chen and Chen [41] use panel cointegration to analyze the long-run relationship between real oil prices and exchange rates by using a monthly panel data of G7 countries. They find that oil prices have been the dominant source of exchange rate movements and have significant predictive power. Bayat et al. [42] take advantage of a wide range of time series econometric methods such as linear causality, nonlinear causality, volatility spillover and frequency domain causality analysis and find that oil price fluctuations affect real exchange rates in the long-term in Poland and Czech Republic. Brahmasrene et al. [43] examine the causality behavior between oil prices and exchange rates in five oil-exporting countries. They find that exchange rates Granger caused oil prices in the short-run but oil prices Granger caused exchange rates in the long-run and the effects of extreme price volatility in June 2008 on exchange rates was significant. Using several econometric methods including 
192

cointegration, VAR and GARCH, Zhang et al. [44] find a significant cointegration relationship and mean spillover from dollar exchange rate to oil prices but this mean spillover does not work in the reverse direction.

Contrasting these findings, researchers have reported statistically insignificant or numerically weak relationships between the Norwegian Krone and the oil price [45-47]. Similarly, there has been substantial reluctance in labeling the Canadian dollar as a petrocurrency, with researchers again reporting insignificant [48] or even negative relationships. Finally, in a study of the world's largest oil exporters, Russia, Norway and Saudi Arabia, Habib and Kalamova [49] find that the oil price influences the movements of the Russian ruble, but that the currencies of major oil producers Norway and Saudi Arabia remain unaffected by price volatility.

However, the relationship between the price of oil and the exchange rate may be much more complex than what the initial terms of trade effects suggest. Reverse causality, i.e., exchange rates influencing oil price, is possible. Several transmission mechanisms could underpin such reverse causality. First, since oil is denominated in the US dollars, a weaker dollar might lead to an increase in the demand for oil in non-dollar economies, which would cause the oil price rise. Second, if oil production countries have target export revenue in their currencies to finance their government budget deficit, then with a weaker dollar they might reduce the supply of oil in order to drive up the price to achieve their targeted export revenue.

Beckmann and Czudaj [50] use monthly data for different oil-exporting and oil-importing countries and find that causality is a two-way directional. On the one 
214 hand, changes in nominal oil price trigger real exchange rate effects through the 215 nominal exchange rate and the price differential. Reversed causality can also be observed as shocks in nominal exchange rates also influence nominal oil prices in

217 some cases. Sadorsky [51] shows the causality behavior running from exchange rates to oil prices. Akram [52] reveals that a weaker dollar leads to higher oil prices.

The nonlinearity of oil-exchange rate relationships is another issue in the existing studies. A few of studies have investigated the relationships between oil price shocks include GARCH, Copula, nonlinear causality and detrended cross-correlation analysis (DCCA). For example, Reboredo [15] finds little evidence of extreme dependence and exchange rate in a nonlinear framework. The methods used in these studies between oil prices and exchange rates using a number of copulas. Narayan et al. [53] use generalized autoregressive conditional heteroskedasticity (GARCH) and exponential GARCH models to investigate the impacts of oil price changes on Fiji-US exchange rate. Their empirical results indicate that an increase in oil prices causes an appreciation of Fijian dollar against US dollar. Ghosh [11] uses GARCH and EGARCH and also reveals the depreciation of Indian currency vis-à-vis US dollar when oil returns increase. Reboredo and Rivera-Castro [54] employ a wavelet decomposition approach to investigate the dependence between oil price and exchange rate of major currencies against US dollar. They find that oil prices and exchange rates are not dependent in pre-crisis period and that oil prices led exchange rates in post-crisis period. Uddin et al. [55] try to sort out the relationships between oil prices and exchange rates of Japanese yen within both time and frequency space using 
wavelet analysis. They find strong evidence of coherency between the change in real oil price and real exchange rates of Japan for short and medium month cycles. Reboredo et al. [56] use a detrended cross-correlation analysis (DCCA), a method borrowed from statistical physics, and find that the negative dependence between oil and US dollar increased after global financial crisis in 2008-2009 for all time scales. Bouoiyour et al. [57] investigate the nexus between oil price and Russia's real exchange rates using wavelet analysis and find that the oil-exchange rate linkages depend on GDP, government expenditures, terms of trade and productivity differential. Bal and Rath [58] employ Hiemstra and Jones nonlinear test and find the significant nonlinear causality between oil prices and exchange rates of India and China. Table 1 lists a comparison between models used in existing studies and our SVAR.

\section{Insert Table 1 here}

\section{Data and preliminary analysis}

\subsection{Data}

In this paper, we focus on the effects of oil price changes on the U.S. dollar exchange rates against currencies of 16 countries from the Organization for Economic Co-operation and Development (OECD). These 16 countries are Australia, Canada, Czech Republic, Denmark, Hungary, Iceland, Japan, Korea, Mexico, New Zealand, Norway, Poland, Sweden, Switzerland, Turkey and United Kingdom ${ }^{3}$. Among them, Canada, Norway and Mexico are oil-exporting countries and the others are oil-importing countries. Canada is the largest non-OPEC oil exporter for the United

\footnotetext{
3 We exclude the exchange rates of currencies in Eurozone countries.
} 
States. The U.S. is the largest oil importer in the worldwide and two Asian countries (Japan and Korea) import the most among the other countries under consideration.

We investigate the effects of oil shocks on exchange rates over the period from January 1990 to December 2014, which provides 300 monthly observations. The monthly exchange rates of the U.S. dollar again the currencies of 16 OECD countries are collected from the website of OECD (www.oecd.org). The exchange rates are expressed by local currencies per U.S. dollar. Hence, a higher (lower) exchange rate implies an appreciation (depreciation) of the U.S. dollar. We deflate the nominal oil prices using the U.S. consumer price index (CPI) to construct real crude oil prices. CPI data is available at Federal Reserve Bank of Saint Louis (https://research.stlouisfed.org/fred2/). The exchange rate of the US dollar against the currency in a specific country is denoted by the abbreviation of this country's name.

We use the SVAR framework proposed by Kilian(2009) to decompose oil price changes into oil supply shock, aggregate demand shock and other oil-specific demand shocks. The monthly global oil production is taken as the proxy of world oil supply. To quantify global real economic activity, we use Kilian's alternative measure which is based on a global index of dry cargo single voyage freight rates ${ }^{4}$. Kilian's index is also employed in some of recent related studies [59-61]. We choose the WTI crude oil as the underlying oil market because it is a type of crude oil used as a benchmark in oil pricing internationally. It is also the underlying commodity of widely traded

\footnotetext{
4 We obtain the data for this measure from Kilian's website: http://www-personal.umich.edu/ lkilian. For the detailed description, please see the seminal work of Kilian [5].
} 
futures contracts in the New York Mercantile Exchange. The data of WTI oil prices and global oil production are collected from the Energy Information Administration (EIA) in the United State Department of Energy (www.eia.gov). Global oil production, Kilian's index for global economic activity and oil price are denoted by "GOP”, "KI” and "OP”, respectively.

\subsection{Unit root and co-integration tests}

Previous studies find that our variables of interests may not be stationary and contain unit roots. To ensure the stationary properties for our following analysis, we conduct unit root tests using ADF, PP and KPSS tests, respectively ${ }^{5}$. The optimal lag length of ADF test is chosen based on Schwarz Information Criterion (SIC) and the optimal bandwidths of PP and KPSS tests are determined based on Newey-West criterion.

Tables 2 and Table 3 report the results of unit root tests for the original time series and the series after taking the first difference, respectively. We find that most time series of our variables of interests contain the unit roots. However, after taking the first difference, KPSS statistics show that only 4 exchange rate series are not stationary. ADF and PP statistics clearly suggest that all the first order difference series are stationary. Therefore, we can generally conclude that oil production, global economic activity, oil price, and exchange rate series have unit roots but their first order differences are stationary.

\footnotetext{
5 To save space, we do not give the detailed description of these three unit root tests.
} 

exchange rates. The results are reported in Table 4 . We can find that the null hypothesis of no cointegration is rejected only for HUN, MEX, POL and TUR. In sum, the null hypothesis of no co-integration relationship cannot be rejected for 10 out of 16 cases. This confirms that VAR model is appropriate and superior to vector error correction (VEC) model in terms of short-run forecast variance. Therefore, we will use VAR model to describe joint dynamics between changes in oil prices and changes in exchange rates.

\section{Insert Table 4 here}

\subsection{Nonlinearity test}

VAR implies the linear relationships between different economic variables but neglect the possible nonlinearity. Prior to investigate the oil-exchange rate relationships using VAR, we first test for nonlinearity between oil price changes and exchange rates to ensure whether linear specification can perform well. We use both parametric and nonparametric methods to examine nonlinearity.

We use the parametric method to test for asymmetry in oil-exchange rate relationships. There is an important issue on oil-macroeconomy relationship is whether economic variables respond asymmetrically to oil price shocks. A large number of studies show the evidence of asymmetry [10, 2, 3, 12] whereas some of recent studies do not support their findings [6-8]. However, to the best of our knowledge, whether exchange rates respond asymmetrically to oil price changes has not been investigated. In this subsection, we will fill this gap. Following Mork [10], 
our model specification of asymmetry test can be written as follows:

$$
\Delta e r_{t}=c+\sum_{i=1}^{j} \alpha_{i} \Delta e r_{t-i}+\sum_{i=1}^{j} \beta_{i} \Delta o p_{t-i}+\sum_{i=1}^{j} \gamma_{i} \Delta o p_{t-i}^{\#}+\varepsilon_{t}
$$

where $c$ is the constant term, $\Delta o p_{t}^{\#}$ is the proxy of asymmetric oil price change, $\Delta e r_{t}$ is the change of log exchange rate and $\varepsilon_{t}$ is the Gaussian errors. To be consistent with our main VAR model, the lag length $\mathrm{j}$ is set to be 6 .

We use two specifications of asymmetric oil price change. The first is $\Delta o p_{t}^{\#}=\Delta o p_{t}^{+}=\max \left(0, \Delta o p_{t}\right)$. This is motivated by Mork [10] who argues that oil price increases have stronger impacts on macroeconomy than decreases in magnitude. However, Hamilton [2] points out that many increases in crude oil prices are corrections to previous decline, rather than increases from a stable environment. For the purpose of correctly measuring the impacts of oil price changes on economic activity, Hamilton [2] introduces the net oil price change $\left(\Delta n o p_{t}\right), \Delta n o p_{t}=\max [0$, $\left.o p_{t}-\max \left(o p_{t-1}, o p_{t-2}, \ldots, o p_{t-n}\right)\right]$. We take $\Delta n o p_{t}$ as the second asymmetric oil price change and the lag length $n$ is also set to be 6 . Regardless of which measure of asymmetric oil price change is used, The null hypothesis that "the optimal one-period-ahead forecast of stock prices is linear in past values of oil price changes" can be tested by examining whether $\gamma_{1}=\gamma_{2}=\ldots=\gamma_{6}=0$ [12]. A chi-square statistic for Wald test can be employed to perform this nonlinearity test.

Table 5 reports the results of asymmetric test. We can find that the chi-square statistics show rejections of null hypothesis of symmetric relationships only for 2 of 16 countries. In sum, we find little evidence of asymmetry.

\section{Insert Table 5 here}



price-exchange rate relationships such as high moment comovement, structural breaks, regime shifts and tail dependence. We do not know which type of nonlinearity or how many forms of nonlinearity exists in the oil price-exchange rate linkages. Testing all possible forms of nonlinearity will spend too much time and is of too high burden of calculation. To solve this problem, we use a nonparametric Granger causality test conventional causality test is that it is nonparametric and therefore does not rely on the specification of test equation. This method can be used to examine both linear and macroeconomic variables to innovations in real price of oil. Our finding of linear 
plausible explanation of this inconsistency is that we use monthly data while the data frequency in these studies is daily or even higher. Higher frequency data are noisier and thereby present more significant nonlinear properties such as regime switching and extreme volatility. The absence of nonlinearity reduces the likelihood of model misspecification in this paper and increases the credibility of our results based on linear VAR.

\section{Insert Table 6 here}

\section{Method}

Most of previous studies on the impact of oil price changes on the exchange rates focus on one way causality and treat the oil price changes as exogenous. As pointed out by Kilian [5], there are two-way causalities, that is, macroeconomic variable such as oil supply and demand also have impacts on the oil price changes. In addition, it is important to distinguish the oil price changes due to different shocks. Kilian [5] use a structural VAR (SVAR) framework to decompose shocks from demand and supply. We follow his procedure. To investigate the impacts of different oil supply and demand shocks on exchange rates, we introduce a four-variable vector $\mathbf{y}_{t}=\left(\triangle G O P_{t}\right.$, $\left.\Delta K I_{t}, \Delta o p_{t}, \Delta e r_{t}\right)^{\prime}$, where $\Delta$ is the first order difference operator. GOP, $K I, o p$ and er are, respectively, logarithmic global oil production, Kilian's index for global economic activity, logarithmic oil price and logarithmic exchange rate.

The standard structural VAR model is given by:

$$
\mathbf{A y}_{t}=\boldsymbol{\alpha}+\sum_{i=1}^{j} \mathbf{B}_{i} \mathbf{y}_{t-i}+\boldsymbol{\varepsilon}_{t},
$$

where $\boldsymbol{\varepsilon}_{t}$ denotes the vector of structural changes, which is serially and mutually 
independent, $j$ is the optimal lag length. We choose the lag length as $j=6^{6}$.

Following Kilian [5] and Kilian and Park [19], we decompose the error terms implied by reduced-form VAR using the representation $\mathbf{e}_{t}=\mathbf{A}^{-1} \boldsymbol{\varepsilon}_{t}$, that is,

$$
\mathbf{e}_{t}=\left[\begin{array}{l}
e_{t}^{\Delta G O P} \\
e_{t}^{\Delta K I} \\
e_{t}^{\Delta o p} \\
e_{t}^{\Delta e r}
\end{array}\right]=\left[\begin{array}{llll}
a_{11} & 0 & 0 & 0 \\
a_{21} & a_{22} & 0 & 0 \\
a_{31} & a_{32} & a_{33} & 0 \\
a_{41} & a_{42} & a_{43} & a_{44}
\end{array}\right]\left[\begin{array}{l}
\varepsilon_{t}^{\mathrm{oss}} \\
\varepsilon_{t}^{\mathrm{ads}} \\
\varepsilon_{t}^{\mathrm{oos}} \\
\varepsilon_{t}^{\mathrm{oers}}
\end{array}\right],
$$

where $\varepsilon_{t}^{\text {oss }}, \varepsilon_{t}^{\text {ads }}, \varepsilon_{t}^{\text {oos }}$ and $\varepsilon_{t}^{\text {oers }}$ denote oil supply shock, aggregate demand shock, other oil-specific shocks and other exchange rate-specific shocks, respectively.

The short-term restrictions of structural VAR on oil price shocks strictly follow Kilian [5] and Kilian and Park [19]. It should be noted that oil shocks are assumed to exogenous to exchange rates in the short-term. It is impossible that the exchange rate of a small open economy can affect oil supply, demand or price in the short-term (within one month) [62]. This assumption is consistent with the existing studies that treat oil price as an exogenous variable to the U.S. economy within one month [19].

As VAR results depend on the lag length and the variables, we also check the robustness of main VAR results. First, we use an alternative volatility-adjusted oil price measure. Second, we add more economic variables related to exchange rates in the VAR. Third, we use a different VAR lag length.

\section{The effects of oil price shocks on exchange rates}

\subsection{The cumulative responses of exchange rates of the U.S. dollar to oil price shocks}

We perform the Cholesky decomposition on the structural VAR in Eq.(2) and

\footnotetext{
${ }^{6}$ We use several criteria to check the optimal lag length (AIC, BIC, LR, FPE and HQ) for each VAR model. Different criteria yield inconsistent optimal lag lengths, with some less than 6 and some larger than 6 , just like the results in Park and Ratti [63]. Also, based on lag length of 6, we can obtain relatively precise responses.
} 
investigate the responses of U.S. dollar exchange rates to oil price shocks. Figure 1 shows the cumulative responses of exchange rates of U.S. dollar against the currencies in 16 OECD countries to oil supply shock. We can see that the responses of the exchange rates in most countries are not significant at each month after one structural standard deviation shock. The plausible explanation is that the impacts of oil supply shocks on oil price change are not significant in recent years [11].

\section{Insert Figure 1 here}

Figure 2 plots the accumulative responses of the exchange rates to oil demand shock. We can see that the responses are negative for most countries and are significant within the period of first several months after the shock for 7 out of 16 countries. The increases in global economic activity can result in the increases in oil demand of the U.S.. Higher oil demand leads to more oil imports from oil-exporting countries, deteriorates the terms of trade of the U.S. and improves the terms of trade of oil-exporting countries. Thus, the increase in oil demand can result in the depreciation of U.S. dollar against currencies in oil-exporting countries, i.e., the decreases in the exchange rates.

\section{Insert Figure 2 here}

Kilian et al. [24] find that aggregate demand shocks have negative impacts of oil trade balance of oil-importing countries but do not have significant effects on their non-oil trade balance within a short period of time after the shock. Thus, aggregate demand shocks can deteriorate trade balance in oil-importing countries. Golub [64] shows that the analyses of effects of oil price change on exchange rates should be 
related to the relative change of situations of two countries. The increase in oil price driven by aggregate demand can deteriorate the situations in the other oil-importing countries but because they import less oil relatively to the U.S. ${ }^{7}$, their situation relative to the U.S. can be improved. Eventually, the increase in oil price can cause the appreciation of currencies in the other oil-importing countries against the U.S. dollar, i.e., the depreciation of the dollar.

With the time elapses, the responses of exchange rates to aggregate demand shock are not significant for any of the countries. The reason is that the increase in aggregate demand can finally trigger higher demand of non-oil goods. Oil-exporting countries and the other oil-importing countries may imports more non-oil goods from the U.S. which is helpful to restore the external balance of the U.S.. Kilian et al. [5] also find that after 2-4 years aggregate demand shocks have positive impacts on non-oil trade balance of oil-importing countries and have negative effects on non-oil trade balance of oil-exporting countries. With the time goes by, the negative impacts of higher oil price caused by increases in global economic activity (e.g., the higher inflation rate) may deteriorate the terms of trade of the trading partners of the U.S., which is also helpful to the improvement of the relative situation of the U.S..

Figure 3 shows the accumulative responses of the bilateral exchange rates of the U.S. dollar to other oil-specific shocks. Kilian [5] attributes this type of pure changes in oil price which cannot be explained by the change of supply or demand to the precautionary demand. We can find that the responses of exchange rates of U.S. dollar

\footnotetext{
7 The U.S. is the largest oil importer in the worldwide.
} 
against currencies in most countries are significantly negative within the first several months after the shock. The reason is that these pure changes in oil price lead to wealth transfer from oil-importing countries to oil-exporting countries. Thus, an oil-specific shock results in the depreciation of the dollar against currencies in oil-exporting countries [65]. As the U.S. imports more oil than the other oil-importing countries, increases in oil prices can also improve the situation of other oil-importing countries relative to the U.S.. With the time elapses, we can see that the responses of exchange rates of dollar against currencies in most countries become insignificant. The plausible explanation is that the short-term elasticity of oil demand is different from the long-term elasticity. In the short-term the elasticity of oil demand is well below unity [34]. One can observe small changes in oil demand when oil price increases. Thus, pure increases in oil price can cause higher deficit in the terms of trade. In the long-term, demand elasticity is much larger. Pure increases in oil price leads to greater reduction of oil demand of the U.S. in the long-term, improving the current account of the U.S. and partly offsetting the negative impacts of other oil-specific shocks on the dollar exchange rates. This result can be also explained by the finding in Bodenstein et al. [65] that after the oil market-specific shock the improvement in the non-oil balance can largely dampen its effect on the total balance.

\section{Insert Figure 3 here}

\subsection{Results of variance decomposition}

Figure 4 and Figure 5 show the results of forecasting error variance decomposition of exchange rates for the horizons of 1 month (short-term) and 12 
months (long-term), respectively. We can see that the percent contributions of oil price shocks to variations in exchange rates of U.S. dollar are much greater in the long-term than in the short-term. In the short-term oil price shocks can explain no more than $10 \%$ of the variations in exchange rates of dollar against currencies in most countries.

In the long-term, the percent contributions of oil price shocks are about $10 \%-20 \%$, depending on the currency under consideration. Both in the short-term and long-term the contributions of aggregate demand shock and other oil-specific shock are greater than the contribution of oil supply shock, reinforcing the empirical results based on impulse response analysis. More importantly, the contributions of oil price shocks to variations in exchange rate of U.S. dollar against Canadian dollar and Norwegian krone are greater than to the exchange rates of U.S. dollar against the other currencies. The reason is that Canada and Norway and the U.S. are more closely linked in the term of oil trading. For example, Canada is the largest crude oil trading partner of the U.S. among non-OPEC countries. More than $40 \%$ of U.S.'s oil imports from non-OPEC countries are due to Canada's exports.

\section{Insert Figure 4 and Figure 5 here}

\subsection{A Robustness check-sensitive analysis using the alternative lag length}

In our main VAR model, the lag length is set to be 6 . For robustness, we perform a sensitive analysis by adjusting the lag length to be 12 and then analyzing the impulse responses of real exchange rates to oil supply and demand shocks. We find that the accumulative responses of real exchange rates implied by $\operatorname{VAR}(12)$ are very similar to those implied by $\operatorname{VAR}(6)$, confirming the robustness of our main results. To 
493

494

495

496

497

498

499

500

501

502

503

504

505

506

save space, we do not show the figures of impulse responses but they are available upon request.

\subsection{The role of oil price variability}

Lee et al. [20] argue that the effects of oil price shocks on the macroeconomy during the period when oil price change is relatively stable are different from the effects during the period when oil price change is relatively fierce. For this reason, they point out that researchers should consider the variability of oil price when they analyze the effects of an oil price shock on the economic variables. For robustness check, we use an alternative oil price measure constructed by Lee et al. [20] to investigate the impacts of oil price shocks on the exchange rates of the U.S. dollar. Lee et al. [20] employ a $\operatorname{GARCH}(1,1)$ to model oil price volatility which can be expressed as follows:

$$
o p_{t}=\alpha+\sum_{i=1}^{p} \beta_{i} o p_{t}+\varepsilon_{t}, \quad \varepsilon_{t} I_{t-1} \sim \mathrm{N}\left(0, h_{t}\right), \quad h_{t}=\theta_{0}+\theta_{1} \varepsilon_{t-1}^{2}+\theta_{2} h_{t-1},
$$

where $o p_{t}$ is the oil price return at month $t, \varepsilon_{t}$ is an error term and $h_{t}$ is the conditional variance with the sufficient conditions $\theta_{0}>0, \theta_{1} \geq 0, \theta_{2} \geq 0$ to ensure $h_{t}>0$. We also set the lag length to be six $(\mathrm{p}=6)$, consistent with previous SVAR-based analysis. This variance adjusted oil price measure is defined as:

$$
\operatorname{vop}_{t}=\hat{\varepsilon}_{t} / \sqrt{\hat{h}_{t}} \text {. }
$$

We use this alternative oil price measure and thus the autoregressive vector is replaced by $\mathbf{y}_{t}=\left(\Delta G O P_{t}, \Delta K I_{t}, \Delta v o p_{t}, \Delta e r_{t}\right)^{\prime}$. We find that the responses of exchange rates almost have no change when this alternative measure of oil price is used. This result indicates that our main findings are not affected by the oil price 
volatility. To save space, we do not show the responses to oil price shocks when we use the alternative oil price measure. They are very similar to the impulse responses shown in Section 5.2 and are available upon request.

\subsection{Adding other variables}

It is possible that oil price changes can affect exchange rates by influencing other macroeconomic determinants of exchange rates. For example, oil price increases can result in higher inflation rate [1]. As a response to higher inflation rates caused by increases in oil prices, the Federal Reserve may implement the monetary policy by adjusting interest rates [23]. The theory of interest rate parity (IRP) shows that relative changes of two country's interest rates can result in the changes of bilateral (nominal) exchange rates. The exchange rate is intrinsically an asset price that will reflect expected future return on the asset. As new information on monetary policy will change the expected return on the asset, exchange rate responds instantaneously to monetary policy [66].

To consider the role of other variables in oil-exchange rate relations, we use an alternative structural VAR by adding the relative interest rate and inflation rate to the VAR expressed by Eq.(1). Therefore, our autoregressive vector $\mathbf{y}_{t}=\left(\Delta G O P_{t}, \Delta K I_{t}\right.$, $\left.\Delta o p_{t}, \Delta \pi_{t}, \Delta i_{t}, \Delta e r_{t}\right)^{\prime}$, where $\Delta \pi_{t}$ is the difference of inflation rate between US and a foreign country and $i_{t}$ is the difference of interest rate. Also, we impose the recursive short-term restrictions on the relationships among these variables. Similarly, we assume that three oil price shocks are exogenous to inflation rate and interest rates. This assumption is consistent with the findings that innovations to oil prices are 
predetermined with respect to the US economy [67]. The similar restrictions can be seen in Kilian and Lewis [22]. The ordering of three macroeconomic variables (relative inflation rate, relative interest rate and exchange rate) is standard and exactly consistent with the related structural VAR literature [67-68].

Based on this new VAR, we calculate the responses of dollar exchange rates to other oil-specific shocks. We find that the responses are generally consistent with the results shown in Figure 3, suggesting that adding more macroeconomic variables does not change our main empirical findings. To save space, we do not show the results but they are available upon request.

\subsection{Sub-sample analysis}

It is well known that the major determinants of oil price shocks change over time. From 2003 to 2008, oil demand in emerging economies such as China and India drive up the oil prices persistently. The large crash of oil prices in mid-2008 due to global financial crisis is a typical demand shock. Oil price decreases after mid-2014 are attributed to higher oil production in Saudi Arabia and Russia. Therefore, it is likely that the effects of oil price shocks on exchange rates change over time. To address this issue, we divide the whole sample into two subsamples and investigate the contributions of three oil shocks to exchange rate variation. Figure 6 and Figure 7 show the results of variance decomposition of exchange rates during pre-crisis and post-crisis periods for the horizon of 12 months, respectively. We can find that after crisis the contributions to oil shocks increase greatly. Three oil shocks can explain about $10 \%-20 \%$ of exchange rate variations during pre-crisis period, depending on the 
currencies. During post-crisis period, more than $40 \%$ of exchange rate variations can be explained by oil shocks. For some oil-exporting countries such as Canada and Mexico, more than $50 \%$ of exchange rate volatility is due to oil market shocks. In summary, we can conclude that oil price shocks plays more important role in dollar exchange rate variations.

\section{Insert Figures 6 and 7 here}

\section{Concluding remarks}

In this paper, we investigate the impacts of oil price shocks on the exchange rates of the U.S. dollar against currencies in 16 OECD countries. We first examine the nonlinear relationships between oil price changes and exchange rates. Using both parametric and nonparametric methods, we find little evidence of nonlinearity. This result indicates that linear VAR model is suitable to capture their joint dynamics.

We use a structural VAR to decompose oil price changes into supply shock, demand shock and other oil-specific shocks and investigate the impacts of different oil shocks on exchange rates. We find that the responses of dollar exchange rates to oil supply shock are not significant, whereas higher oil prices driven by aggregate demand shock and other oil-specific shocks can significantly depreciate the U.S. dollar against currencies in most countries. Employing the method of variance decomposition, we find that oil price shocks can overall explain about $10 \%$ of the short-term exchange rate variations and about $20 \%$ of the long-term exchange rate variations. The explanatory power of aggregate demand shock and other oil-specific shocks are much stronger than oil supply shock. These core findings are further 
demonstrated to be robust to an alternative oil price measure, different lag lengths of VAR and different specifications of VAR.

Our findings also have some important implications. For example, as the responses of exchange rate to an oil shock depend on the driving force behind oil price changes, participants in exchange rate market should pay attention to oil shocks and differentiate what is the major driving force of changes in oil prices. We note that oil price changes not due to supply or demand shocks can lead to appreciation of most currencies against US dollar. This can result in less usefulness of asset diversification. Interestingly, just because other oil-specific shocks due to precautionary demand or market speculation can cause persistent depreciation of dollar exchange rate during first several months after the shock, it is likely that the time series momentum strategy of Moskowitz et al. [69] is useful in exchange rate investment. Policy makers also should differentiate oil demand and supply shocks. As exchange rate is the core determinant of exports and imports, disentangling oil price shocks are helpful to develop macroeconomic policy to maintain the trade balance.

We would like to conclude this paper by outlining some further developments. First, we have found that the impacts of oil shocks are not consistent between pre-crisis and post-crisis periods. Therefore, a structural VAR with time-varying parameters may better capture the change of the impacts over time. Second, not only the mean effect, the volatility spillover from oil to exchange rates markets is of interest and deserve further investigation because volatility has important implications for asset allocation. Third, we have performed detailed in-sample analysis on the 
603

604

605

606

607

608

609

610

611

612

613

614

615

616

617

618

619

620

621

622

623

624

oil-exchange rate relationships but out-of-sample relationships have not been investigated in the literature. It is interesting to find whether oil market information can predict exchange rates out-of-sample. The use of oil market information provides a possible way to solve the seminal "Meese Rogoff" puzzle that economic models cannot significant beat the simple random walk in forecasting exchange rates.

\section{Acknowledgements}

We would like to show sincere gratitude to three anonymous reviewers whose comments and suggestions greatly improved the quality of this paper. This work is supported by the National Science Foundation of China (Nos. 71401077, 71501095 and 71503039) and National Social Science Foundation of China (No.15ZDA053).

\section{References}

[1]Hamilton, J.D. (1983), “Oil and the Macroeconomy since World War II," Journal of Political Economy, Vol. 91, pp. 228-248.

[2]Hamilton, J.D. (1996), “This Is What Happened to the Oil Price-macroeconomy Relationship,” Journal of Monetary Economics, Vol. 38, pp. 215-220.

[3]Hamilton, J.D. (2003), “What Is an Oil Shock?” Journal of Econometrics, Vol. 113, pp. 363-398.

[4]Kilian, L. (2008), "Exogenous Oil Supply Shocks: How Big Are They and How Much Do They Matter for the U.S. Economy?" Review of Economics and Statistics, Vol. 90, pp. 216-240.

[5]Kilian, L. (2009), “Not All Oil Price Shocks Are Alike: Disentangling Demand and 

pp. 1053-1069.

[6]Kilian, L., and R.J. Vigfusson (2011a), “Are the Responses of the U.S. Economy Vol. 2, pp. 419-453. Asymmetric in Energy Price Increases and Decreases?” Quantitative Economics,

[7]Kilian, L., and R.J. Vigfusson (2011b), "Nonlinearities in the Oil Price-output Relationship," Macroeconomic Dynamics, Vol. 15, pp. 337-363.

[8]Kilian, L., and R.J. Vigfusson (2013), “Do Oil Prices Help Forecast U.S. Real GDP? The Role of Nonlinearities and Asymmetries," Journal of Business and Economic Statistics, Vol. 31, pp. 78-93.

[9]Baumeister, C., and L. Kilian (2014), "Understanding the Decline in the Price of Oil since June 2014," Journal of the Association of Environment and Resource Economists, Forthcoming.

[10]Mork, K.A. (1989), “Oil and the Macroeconomy When Prices Go up and down: An Extension of Hamilton's Results," Journal of Political Economy, Vol. 91, pp. 740-744.

[11]Wang, Y., C. Wu and L. Yang (2013), “Oil Price Shocks and Stock Market Activities: Evidence from Oil-importing and Oil-exporting Countries,” Journal of Comparative Economics, Vol. 40, pp. 1220-1239.

[12]Hamilton, J.D. (2011), "Nonlinearities and the Macroeconomic Effects of Oil Prices," Macroeconomic Dynamics, Vol. 15, pp. 364-378.

[13] Ghosh, S. (2011), "Examining crude oil price-Exchange rate nexus for India 
647

648

649

650

651

652

653

654

655

656

657

658

659

660

661

662

663

664

665

666

667

668

during the period of extreme oil price volatility.” Applied Energy, Vol. 88, pp. 1886-1889.

[14] Salisu, A. A., and H. Mobolaji (2013). „Modeling returns and volatility transmission between oil price and US-Nigeria exchange rate.” Energy Economics, Vol. 39, pp. 169-176.

[15] Reboredo, J. C. (2012), "Modelling oil price and exchange rate co-movements." Journal of Policy Modeling, Vol. 34, pp.419-440.

[16] Wu, C. C., H. Chung and Y. H. Chang (2012). "The economic value of co-movement between oil price and exchange rate using copula-based GARCH models." Energy Economics, Vol. 34, pp. 270-282.

[17] Aloui, R., M. S. B. Aïssa, and D.K. Nguyen (2013), “Conditional dependence structure between oil prices and exchange rates: A copula-GARCH approach.” Journal of International Money and Finance, Vol. 32, pp.719-738.

[18] Wang, Y., and C. Wu (2012), "Energy Prices and Exchange Rates of the U.S. dollar: Further Evidence from Linear and Nonlinear Causality Analyses," Economic Modeling, Vol. 29, pp. 2289-2297.

[19] Kilian, L., and C. Park (2009), “The Impact of Oil Price Shocks on the U.S. Stock Market," International Economic Review, Vol. 50, pp. 1267-1287.

[20] Lee, K., S. Ni, and R.A. Ratti (1995), “Oil Shocks and the Macroeconomy: the Role of Price Variability,” Energy Journal, Vol. 16, pp. 39-56.

[21] Bollerslev, T. (1986), “Generalized Autoregressive Conditional Heterskedasticity," Journal of Econometrics, Vol. 30, pp. 307-327. 
669

670

671

672

673

674

675

676

677

678

679

680

681

682

683

684

685

686

687

688

689

690

[22] Kilian, L., and L. Lewis (2011), "Does the Fed Respond to Oil Price Shocks?” The Economic Journal, Vol. 121, pp. 1047-1072.

[23] Bodenstein, M., L. Guerrieri, and L. Kilian (2012), “Monetary Policy Responses to Oil Price Fluctuations," IMF Economic Review, Vol. 60, pp. 470-504.

[24] Kilian, L., A. Rebucci, and Spatafora, N., 2009. Oil shocks and external balances. Journal of International Economics 77, 181-194.

[25] Ferraro, D., K. Rogoff and B. Rossi, "Can oil price forecast exchange rates? An empirical analysis of the relationship between commodity prices and exchange rates," Journal of International Money and Finance, Vol. 54, pp. 116-141.

[26] Amano, R.A., and S. van Norden (1998a), "Oil Prices and the Rise and Fall of the US Real Exchange Rate,” Journal of International Money and Finance, Vol. 17, pp. 299-316.

[27] Amano, R.A., and S. van Norden (1998b), "Exchange Rates and Oil Prices," Review of International Economics, Vol. 6, pp. 683-694.

[28] Backus, D.K., and M.J. Crucini (2000), "Oil Prices and the Terms of Trade," Journal of International Economics, Vol. 50, pp. 185-213.

[29] Baxter, M., and M.A. Kouparitsas (2000), "What Causes Fluctuations in the Terms of Trade," NBER working paper, No. 7462.

[30] Korhonen, I., and T. Juurikkala (2009), "Equilibrium exchange rates in oil-exporting countries,” Journal of Economics and Finance, Vol. 33, pp. 71-79.

[31] Chaudhuri, K., and B. C. Daniel (1998), “Long-run equilibrium real exchange rates and oil prices," Economics Letters, Vol. 58, 231-238. 
691

692

693

694

695

696

697

698

699

700

701

702

703

704

705

706

707

708

709

710

[32] Zalduendo, J. (2006), “Determinants of Venezuela's Equilibrium Real Exchange Rate,” IMF Working Paper.

[33] Baumeister, C., and G. Peersman (2012), “The Role of Time-varying Elasticities in Accounting for Volatility Changes in the Crude Oil Market," Journal of Applied Econometrics, Vol. 28, pp. 1087-1109.

[34] Kilian, L., and D.P. Murphy (2013), “The Role of Inventories and Speculative Trading in Global Market for Crude Oil," Journal of Applied Econometrics, forthcoming.

[35] Koranchelian, T. (2005), “The Equilibrium Real Exchange Rate in a Commodity Exporting Country: Algeria’s Experience,” IMF Working Paper.

[36] Mongardini, J. (1998), “Estimating Egypt's Equilibrium Real Exchange Rate," IMF Working Paper, No. 98/5.

[37] Spatafora, N., and E. Stavrev (2003), “The Equilibrium Real Exchange Rate in a Commodity Exporting Country: The Case of Russia," IMF Working Paper, No. 03/93.

[38] Oomes, N., and K. Kalcheva (2007), “Diagnosing Dutch Disease: Does Russia Have the Symptoms?” BOFIT Discussion Paper, No.7.

[39] Lizardo, R.A., and A.V. Mollick (2010), “Oil Price Fluctuations and U.S. Dollar Exchange Rates,” Energy Economics, Vol. 32, pp. 399-408.

[40] Sari, R., Hammoudeh, S., \& Soytas, U. (2010). Dynamics of oil price, precious metal prices, and exchange rate. Energy Economics, 32(2), 351-362.

[41] Chen, S.-S., and H.-C. Chen (2007), "Oil Prices and Real Exchange Rates," 
[42] Bayat, T., S. Nazlioglu, and S. Kayhan (2015), "Exchange rate and oil price interactions in transition economies: Czech Republic, Hungary and Poland," Panoeconomics, Vol. 62, pp. 267-285.

[43] Brahmasrene, T., J. C. Huang, and Y. Sissoko (2014), “Crude Oil Prices and Exchange Rates: Causality, Variance Decomposition and Impulse Response," Energy Economics, Vol. 44, pp. 407-412.

[44] Zhang, Y.-J., Y. Fan, H.-T. Tsai, and Y.-M. Wei (2008), "Spillover Effect of US Dollar Exchange Rate on Oil Prices," Journal of Policy Modeling, Vol. 30, pp. 973-991.

[45] Bjørnland, H.C., and H. Hungnes (2008), "The Commodity Currency Puzzle," ICFAI Journal of Monetary Economics, 7-30.

[46] Akram, Q.F. (2004), “Oil Prices and Exchange Rates: Norwegian Evidence. Econometrics Journal, Vol. 7, pp. 476-504.

[47] Akram, Q.F. (2000), “When Does the Oil Price Affect the Norwegian Exchange Rate?" Unpublished Manuscript, University of Oxford.

[48] Gauthier, C., and D. Tessier (2002), "Supply shocks and Real Exchange Rate Dynamics: Canadian Evidence”, Working Paper, Bank of Canada.

[49] Habib, M.M., and M.M. Kalamova (2007), “Are There Oil Currencies? The Real Exchange Rate of Oil Exporting Countries,” ECB Working Paper, No.839.

[50] Beckmann, J., and R. Czudaj (2012), “Oil Prices and Effective Dollar Exchange Rates," International Review of Economics and Finance, Vol. 27, pp. 621-636. 
[51] Sadosky, P. (2000), “The Empirical Relationship between Energy Futures Prices and Exchange Rates," Energy Economics, Vol. 22, pp. 253-266.

[52] Akram, Q.F. (2009), “Commodity Prices, Interest Rates and the Dollar,” Energy Economics, Vol. 31, pp. 838-851.

[53] Narayan, P.K., S. Narayan, and A. Prasad (2008), "Understanding the Oil Price-exchange Rate Nexus for the Fiji Islands," Energy Economics, Vol. 30, pp. 2686-2696.

[54] Reboredo, J. C., and M. A. Rivera-Castro (2013), “A Wavelet Decomposition Approach to Crude Oil Price and Exchange Rate Dependence," Economic Modelling, Vol. 32, 42-57.

[55] Uddin, G. S., A. K. Tiwari, M. Arouri, and F. Teulon (2013), "On the relationships between oil price and exchange rates: A wavelet analysis," Economic Modelling, Vol. 35, pp. 502-507.

[56] Reboredo, J. C., M. A. Rivera-Castro and G. F. Zebende (2014), "Oil and US Exchange Rate Dependence: A Detrended Cross-correlation Approach,” Energy Economics, Vol. 42, 132-139.

[57] Bouoiyour, J., R. Selmi, A. K. Tiwari, and M. Shahbaz (2015), "The Nexus between Oil Price and Russia's Real Exchange Rate: Better Paths via Unconditional vs Conditional Analysis,” Energy Economics, Vol. 51, pp. 54-66.

[58] Bal, D. P., and B. N. Rath (2015), "Nonlinear Causality between Crude Oil and Exchange Rate: A Comparative Study of China and India," Energy Economics, Vol. 51, pp. 149-156. 
757

758

759

760

761

762

763

764

765

766

767

768

769

770

771

772

773

774

775

776

777

778

[59] Apergis, N., and S.M. Miller (2009), "Do Structural Oil-market Shocks Affect Stock Prices?” Energy Economics, Vol. 31, pp. 569-575.

[60] Basher, S.A., A.A. Haug, and P. Sadorsky (2012), “Oil Prices, Exchange Rates and Emerging Stock Markets," Energy Economics, Vol. 34, pp. 227-240.

[61] Jung, H., and C. Park (2011), "Stock Market Reaction to Oil Price Shocks: A Comparison between an Oil-exporting Economy and an Oil-importing economy," Journal of Economic Theory and Econometrics, Vol. 22, pp. 1-29.

[62] Bjørnland, H.C. (2009a), "Oil Price Shocks and Stock Market Booms in an Oil-exporting Country," Scottish Journal of Political Economy, Vol. 56, pp. 232-254.

[63] Park, J., \& Ratti, R. A. (2008). Oil price shocks and stock markets in the US and 13 European countries. Energy economics, 30(5), 2587-2608.

[64] Golub, S. (1983), “Oil Prices and Exchange Rates,” The Economic Journal, Vol. 93, pp. 576-593.

[65] Bodenstein, M., C.J. Erceg, and L. Guerrieri (2011), “Oil Shocks and External Adjustment," Journal of International Economics, Vol. 83, pp. 168-184.

[66] Bjørnland, H.C. (2009b), "Monetary Policy and Exchange Rate Overshooting: Dornbusch Was Right after All," Journal of International Economics, Vol. 79, pp. 64-77.

[67] Kilian, L., and Vega, C. (2011), "Do Energy Prices Respond to U.S. Macroeconomic News? A Test of the Hypothesis of Predetermined Energy Prices," Review of Economics and Statistics, Vol. 93, pp. 660-671. 
779 [68] Eichenbaum, M., and C. Evans (1995), "Some Empirical Evidence on the Effects of Shocks to Monetary Policy on Exchange Rates," Quarterly Journal of Economics, Vol. 110, pp. 975-1010.

782

791

792

793

794

795

796

797

798

799

800

[69] Moskowitz, T. J., Y. H. Ooi, L. H. Pedersen (2012), “Time Series Momentum,” Journal of Financial Economics, Vol. 104, pp. 228-250.

[70] Diks, C., and V. Panchenko (2006), “A New Statistic and Practical Guidelines for Nonparametric Granger Causality Testing,” Journal of Economic Dynamics and Control, Vol. 30, pp. 1647-1669. 
802

803

804

805

806

807

808

809

810
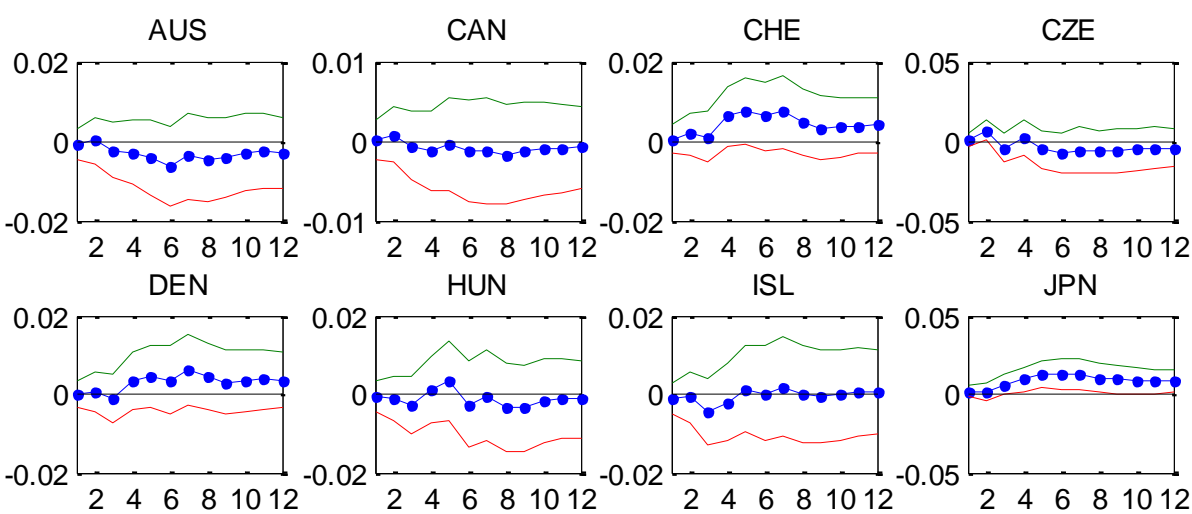

ISL JPN
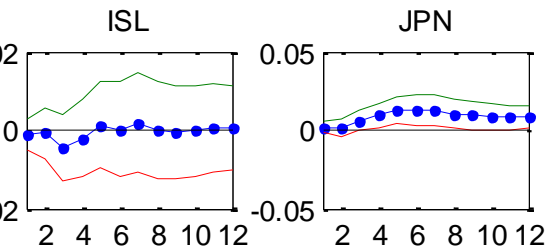

KOR

MEX

NOR

NZL
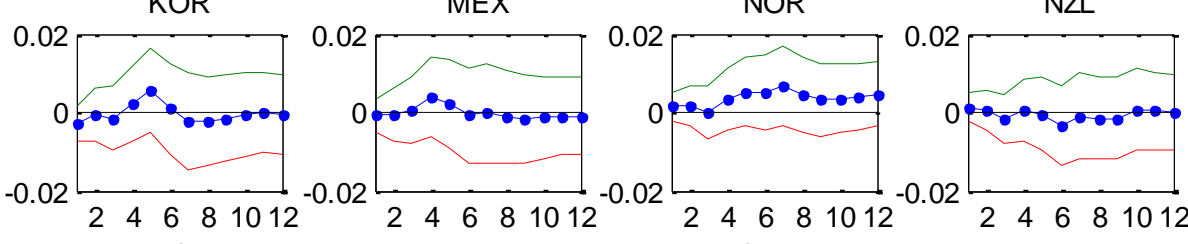

SWE

UK
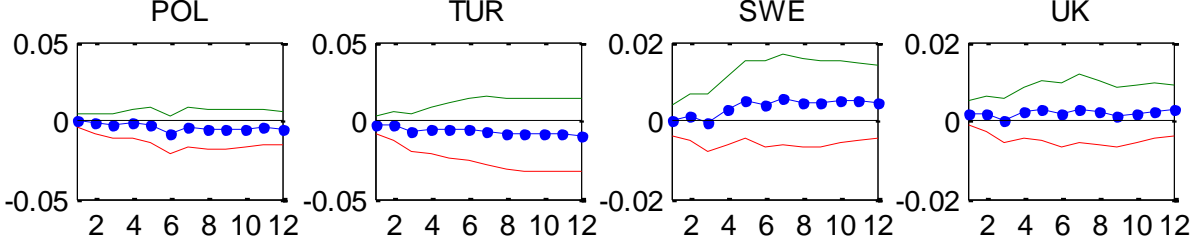

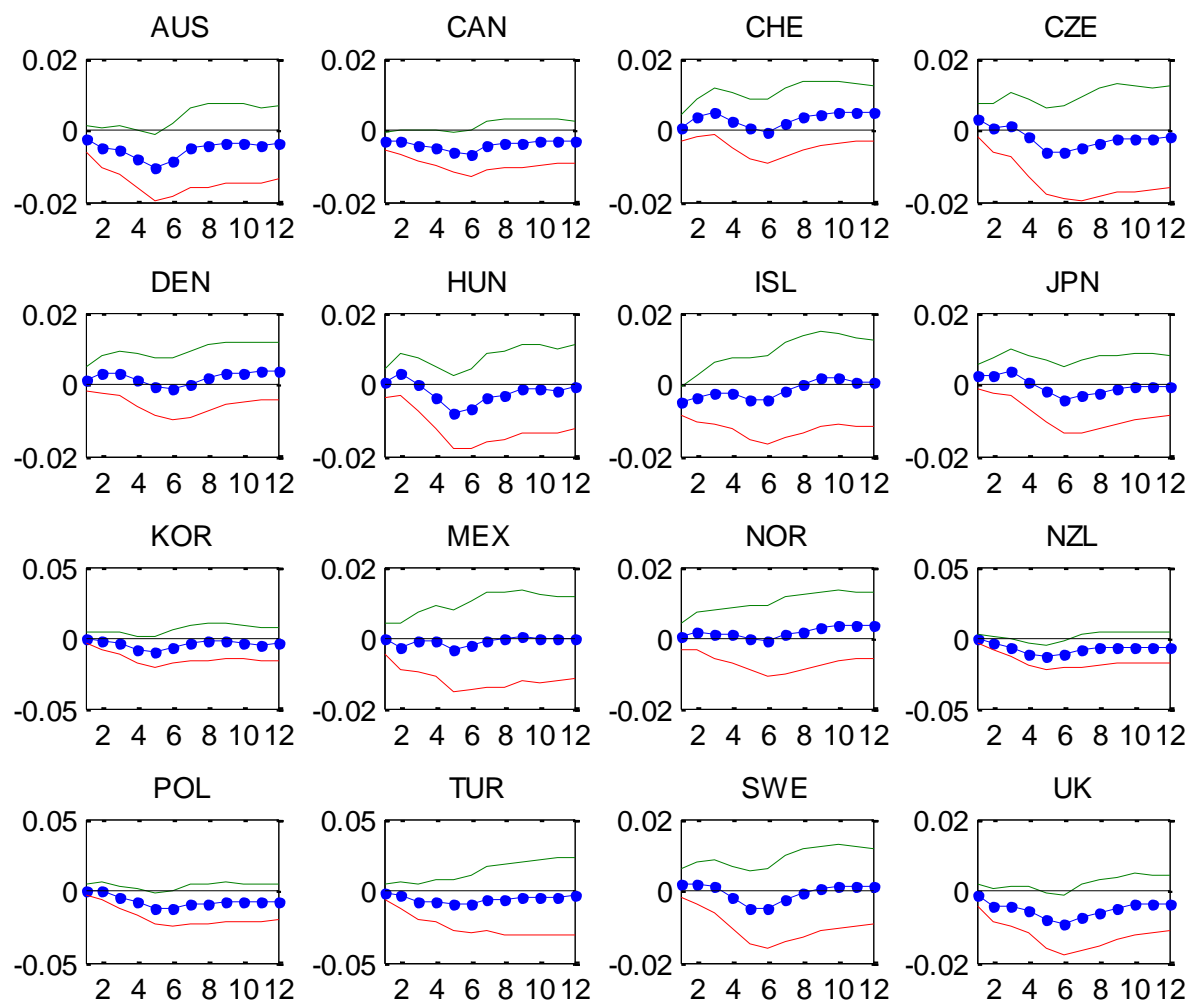

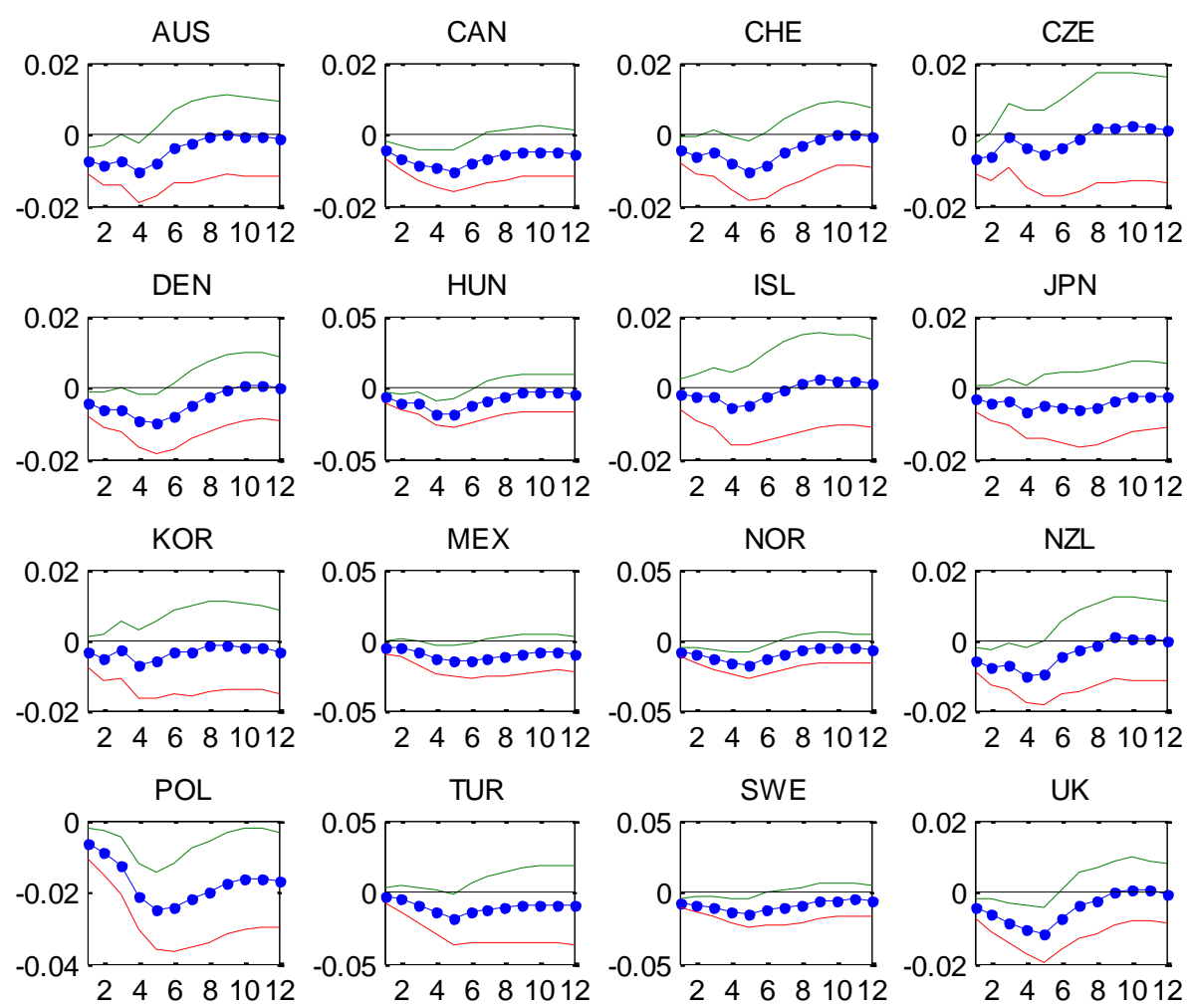


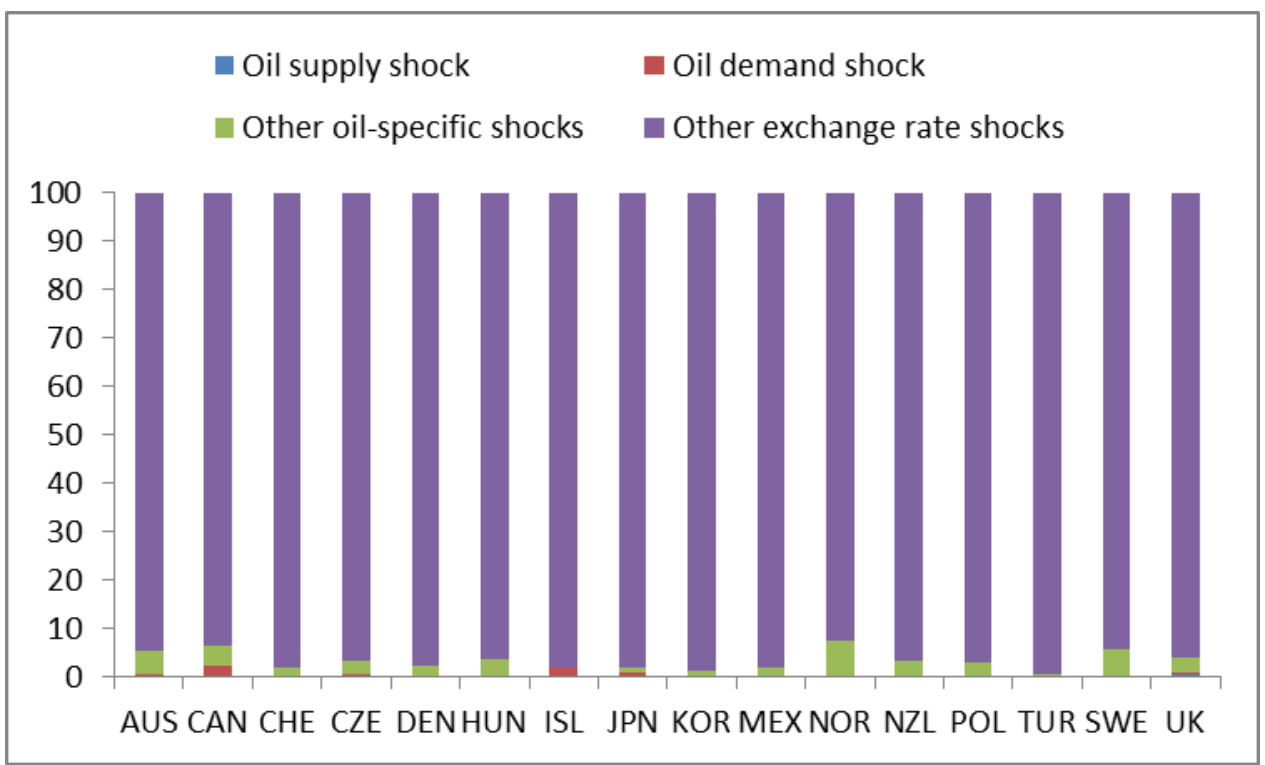

Figure 4 Decompositions of exchange rate variations for the horizon of 1 month 


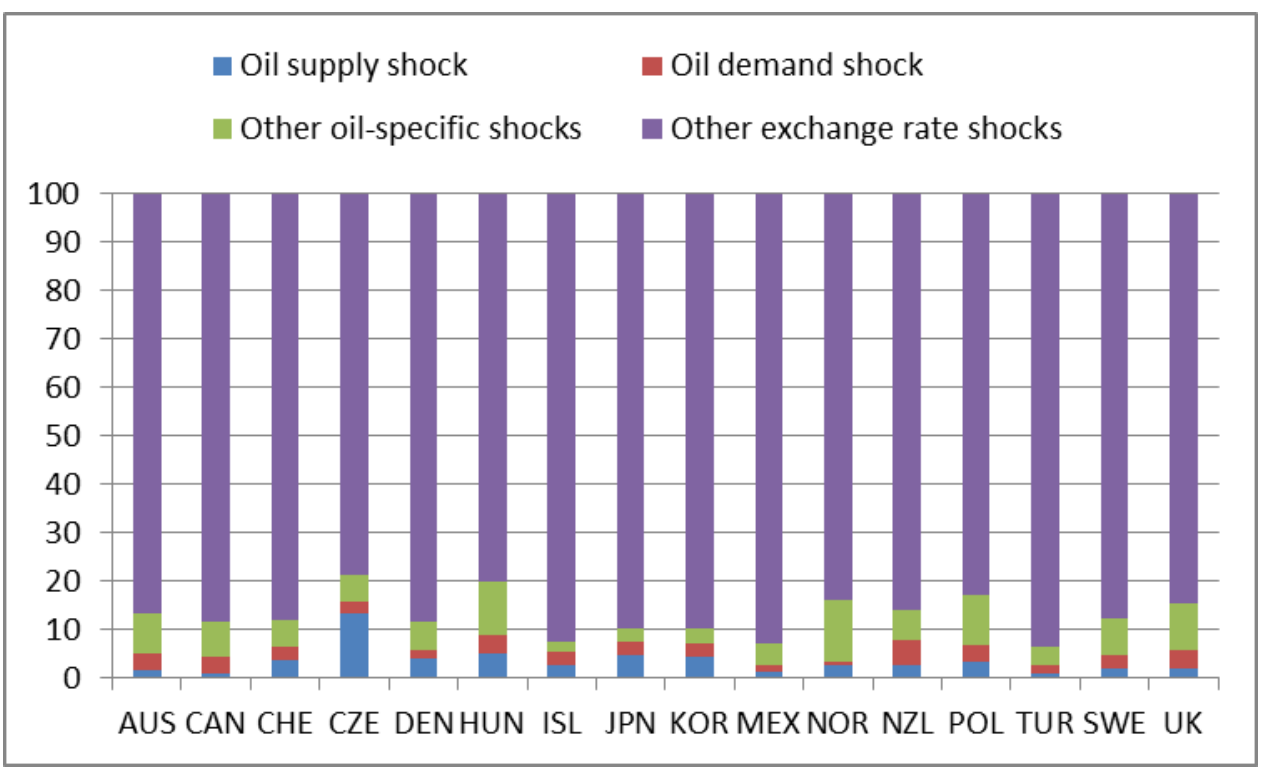

914

915

916

917

918

919

920

921

922

923

924

925

926

927

928 


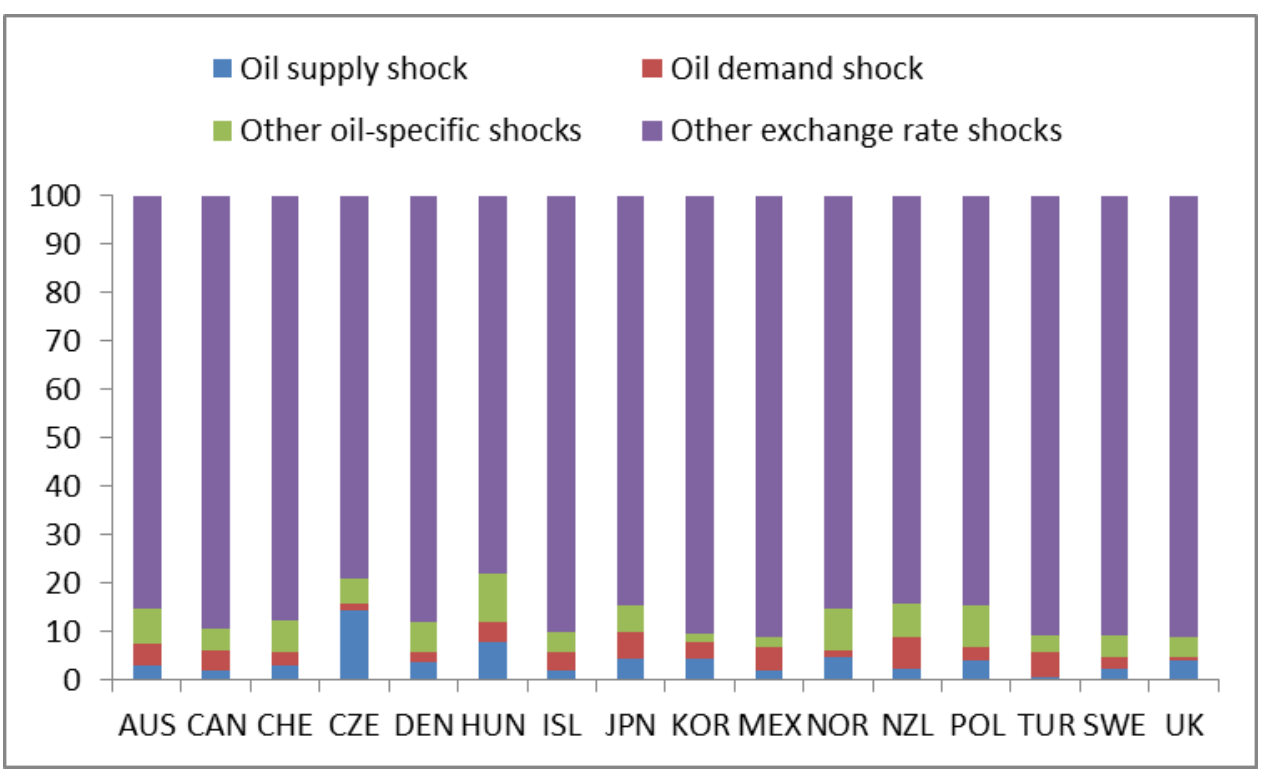

Figure 6 Variance decomposition of exchange rates during pre-crisis period 


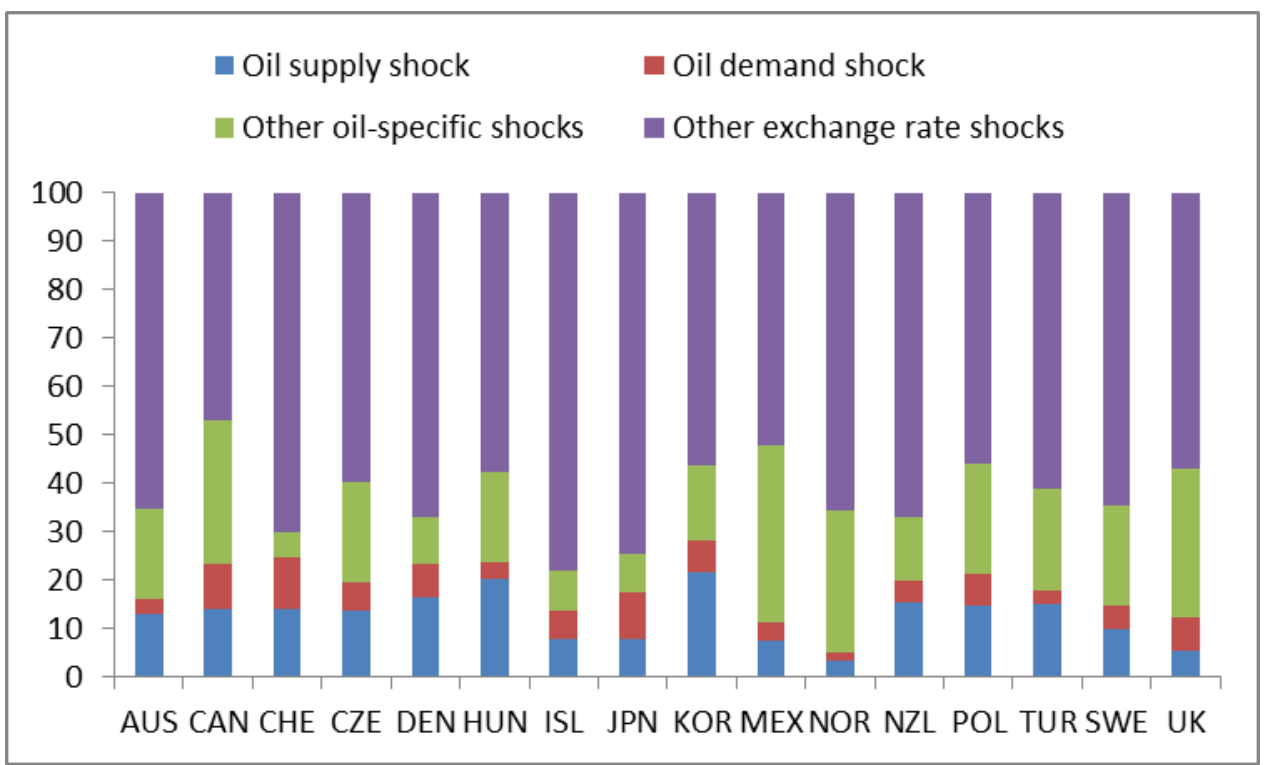

977

Figure 7 Variance decomposition of exchange rates during post-crisis period

978

979

980

981

982

983

984

985

986

987 
990

991

992

993

994

995

996

Table $1 \mathrm{~A}$ list of models used in existing studies

\begin{tabular}{|c|c|c|c|c|}
\hline Model & Input & Output & Assumption & Key references \\
\hline $\begin{array}{l}\text { VAR- or } \\
\text { ECM-based } \\
\text { models }\end{array}$ & $\begin{array}{l}\text { Oil price and } \\
\text { exchange rate }\end{array}$ & $\begin{array}{c}\text { Cointegration and } \\
\text { causality }\end{array}$ & $\begin{array}{l}\text { Linear price } \\
\text { relationship }\end{array}$ & $\begin{array}{l}\text { Amano and van Norden (1998a, 1998b), } \\
\text { Chaudhuri and Daniel (1998), Sari et al. } \\
\text { (2012) }\end{array}$ \\
\hline GARCH & $\begin{array}{l}\text { Oil price and } \\
\text { exchange rate }\end{array}$ & Volatility spillover & $\begin{array}{l}\text { Volatility } \\
\text { relationship }\end{array}$ & $\begin{array}{l}\text { Zhang et al. (2008), Ghosh (2011) and } \\
\text { Narayan et al. (2008) }\end{array}$ \\
\hline DCCA & $\begin{array}{l}\text { Oil price and } \\
\text { exchange rate }\end{array}$ & Cross-correlation & $\begin{array}{l}\text { Nonlinear } \\
\text { relationship }\end{array}$ & Reboredo et al. (2014) \\
\hline $\begin{array}{l}\text { Wavelet } \\
\text { analysis }\end{array}$ & $\begin{array}{l}\text { Oil price and } \\
\text { exchange rate }\end{array}$ & Coherence & $\begin{array}{l}\text { Nonlinear } \\
\text { relationship }\end{array}$ & $\begin{array}{l}\text { Reboredo and Rivera-Castro (2013), } \\
\text { Uddin et al. (2013) and Bouoiyour et al. } \\
\text { (2015) }\end{array}$ \\
\hline Copula & $\begin{array}{l}\text { Oil price and } \\
\text { exchange rate }\end{array}$ & Dependence & $\begin{array}{l}\text { Nonlinear } \\
\text { relationship }\end{array}$ & Reboredo (2012) \\
\hline SVAR & $\begin{array}{l}\text { Exchange rate, } \\
\text { oil price and } \\
\text { oil supply and } \\
\text { demand } \\
\text { fundamentals }\end{array}$ & $\begin{array}{l}\text { Impulse response } \\
\text { and variance } \\
\text { decomposition }\end{array}$ & $\begin{array}{l}\text { Linear price } \\
\text { relationship }\end{array}$ & Current paper \\
\hline
\end{tabular}

997

998

999 
Table 2 Results of unit root tests for original series

\begin{tabular}{|c|c|c|c|c|c|c|}
\hline & \multicolumn{2}{|c|}{$\mathrm{ADF}$} & \multicolumn{2}{|c|}{ PP } & \multicolumn{2}{|c|}{ KPSS } \\
\hline & $\begin{array}{c}\text { Intercept } \\
\text { only }\end{array}$ & $\begin{array}{l}\text { Intercept } \\
\text { and trend }\end{array}$ & $\begin{array}{c}\text { Intercept } \\
\text { only }\end{array}$ & $\begin{array}{l}\text { Intercept } \\
\text { and trend }\end{array}$ & $\begin{array}{c}\text { Intercept } \\
\text { only }\end{array}$ & $\begin{array}{l}\text { Intercept } \\
\text { and trend }\end{array}$ \\
\hline GOP & -1.232 & $-3.163^{*}$ & -1.195 & -2.977 & $1.821 * * *$ & $0.207 * *$ \\
\hline $\mathrm{KI}$ & -2.522 & -2.749 & -2.512 & -2.742 & $0.788 * * *$ & $0156^{* *}$ \\
\hline OP & -1.123 & -2.921 & -1.078 & -2.991 & $1.663 * * *$ & $0.166^{* *}$ \\
\hline AUS & -1.534 & -1.953 & -1.664 & -2.092 & $0.852 * * *$ & $0.367^{* * *}$ \\
\hline CAN & -0.594 & -2.170 & -0.547 & -2.157 & $1.469 * * *$ & $0.356^{* * *}$ \\
\hline CZE & -1.128 & -1.839 & -1.015 & -1.742 & $0.863 * * *$ & $0.376^{* * * *}$ \\
\hline DEN & -1.566 & -1.818 & -1.378 & -1.637 & $0.835 * * *$ & $0.312 * * *$ \\
\hline HUN & $-3.536 * * *$ & -2.594 & $-3.834 * * *$ & -2.603 & $1.107 * * *$ & $0.390 * * *$ \\
\hline ISL & -0.447 & -1.824 & -0.079 & -1.494 & $1.075^{* * *}$ & $0.212 * *$ \\
\hline JPN & 0.132 & -1.721 & 0.519 & -1.088 & $1.488 * * *$ & $0.313 * * *$ \\
\hline KOR & -2.094 & -2.114 & -2.062 & -2.055 & $0.643^{* *}$ & $0.247 * * *$ \\
\hline MEX & $-4.484 * * *$ & $-3.748 * *$ & $-4.707 * * *$ & $-3.556 * *$ & $1.454 * * *$ & $0.343^{* * *}$ \\
\hline NOR & -1.737 & -2.209 & -1.456 & -1.919 & $0.952 * * *$ & $0.301 * * *$ \\
\hline NZL & -1.825 & -2.468 & -1.413 & -2.153 & $0.925 * * *$ & $0.249 * * *$ \\
\hline POL & $-2.877 * *$ & -2.532 & $-3.347 * *$ & -2.670 & $0.620 * * *$ & $0.401 * * *$ \\
\hline SWE & -1.718 & -2.286 & -1.594 & -2.102 & $1.010 * * *$ & $0.257 * * *$ \\
\hline $\mathrm{CHE}$ & -0.413 & -1.665 & -0.242 & -1.465 & $1.466 * * *$ & $0.356 * * *$ \\
\hline TUR & $-5.514 * * *$ & -2.351 & $-7.642 * * *$ & -2.832 & $1.595 * * *$ & $0.472 * * *$ \\
\hline UK & -1.973 & -1.704 & -1.913 & -1.684 & $0.832 * * *$ & $0.183^{* *}$ \\
\hline
\end{tabular}

Note that this table provides the statistics of unit root tests. The null hypothesis of ADF and PP tests is that the time series contain a unit root while the null hypothesis of KPSS test is that the time series does not contain a unit root. For each of the three unit root tests, we use two different test specifications, one with a constant term and one with both constant and trend terms. Asterisks $*, * *$ and $* * *$ in the table denote rejections of the null hypothesis at $10 \%, 5 \%$ and $1 \%$ significance levels, respectively.

1014 
Table 3 Results of unit root tests for first order difference series

\begin{tabular}{ccccccc}
\hline & \multicolumn{2}{c}{ ADF } & \multicolumn{2}{c}{ PP } & \multicolumn{2}{c}{ KPSS } \\
\hline & Intercept & Intercept & Intercept & Intercept & Intercept & Intercept \\
& only & and trend & only & and trend & only & and trend \\
\hline GOP & $-12.65 * * *$ & $-12.65 * * *$ & $-15.52 * * *$ & $-15.61 * * *$ & 0.053 & 0.027 \\
KI & $-10.47 * * *$ & $-10.45 * * *$ & $-9.019 * * *$ & $-8.993 * * *$ & 0.045 & 0.039 \\
OP & $-12.43 * * *$ & $-12.40 * * *$ & $-12.43 * * *$ & $-12.40 * * *$ & 0.040 & 0.029 \\
AUS & $-16.13 * * *$ & $-16.10 * * *$ & $-16.11 * * *$ & $-16.09 * * *$ & 0.091 & 0.071 \\
CAN & $-10.64 * * *$ & $-10.66 * * *$ & $-10.75 * * *$ & $-10.77 * * *$ & 0.145 & 0.057 \\
CZE & $-10.36 * * *$ & $-10.39 * * *$ & $-10.32 * * *$ & $-10.42 * * *$ & 0.236 & 0.107 \\
DEN & $-10.56 * * *$ & $-10.54 * * *$ & $-10.63 * * *$ & $-10.60 * * *$ & 0.097 & 0.095 \\
HUN & $-9.663 * * *$ & $-10.05 * * *$ & $-9.669 * * *$ & $-9.968 * * *$ & $0.765 * * *$ & $0.217 * * *$ \\
ISL & $-8.819 * * *$ & $-8.888 * * *$ & $-8.947 * * *$ & $-8.979 * * *$ & 0.241 & 0.079 \\
JPN & $-11.62 * * *$ & $-11.71 * * *$ & $-11.66 * * *$ & $-11.70 * * *$ & 0.262 & 0.046 \\
KOR & $-10.19 * * *$ & $-10.19 * * *$ & $-7.921 * * *$ & $-7.886 * * *$ & 0.149 & 0.087 \\
MEX & $-9.647 * * *$ & $-10.20 * * *$ & $-9.801 * * *$ & $-10.20 * * *$ & $0.782 * * *$ & $0.179 * *$ \\
NOR & $-9.603 * * *$ & $-9.580 * * *$ & $-9.512 * * *$ & $-9.488 * * *$ & 0.072 & 0.063 \\
NZL & $-7.616 * * *$ & $-7.609 * * *$ & $-17.19 * * *$ & $-17.18 * * *$ & 0.102 & 0.062 \\
POL & $-5.669 * * *$ & $-5.840 * * *$ & $-9.012 * * *$ & $-9.196 * * *$ & $0.595 * *$ & $0.191 * *$ \\
SWE & $-10.05 * * *$ & $-10.03 * * *$ & $-9.972 * * *$ & $-9.949 * * *$ & 0.058 & 0.056 \\
CHE & $-12.18 * * *$ & $-12.18 * * *$ & $-12.16 * * *$ & $-12.16 * * *$ & 0.146 & 0.073 \\
TUR & $-8.993 * * *$ & $-10.06 * * *$ & $-8.023 * * *$ & $-9.809 * * *$ & $1.653 * * *$ & $0.222 * * *$ \\
UK & $-11.28 * * *$ & $-11.32 * * *$ & $-11.39 * * *$ & $-11.42 * * *$ & 0.136 & 0.065 \\
\hline Nen &
\end{tabular}

Note that this table provides the statistics of unit root tests for the first difference of data series. 
Table 4 Results of cointegration tests

\begin{tabular}{ccccccccc}
\hline & \multicolumn{4}{c}{ Trace statistic } & \multicolumn{4}{c}{ Maximum Eigenvalue statistic } \\
\cline { 2 - 9 } & $r=0$ & $r \leq 1$ & $r \leq 2$ & $r \leq 3$ & $r=0$ & $r \leq 1$ & $r \leq 2$ & $r \leq 3$ \\
\hline AUS & 35.96 & 18.33 & 5.710 & 0.409 & 22.12 & 13.33 & 5.179 & 0.522 \\
CAN & 30.57 & 15.96 & 5.719 & 0.428 & 14.61 & 10.24 & 5.291 & 0.428 \\
CZE & 31.76 & 15.48 & 4.360 & 0.432 & 27.58 & 21.13 & 14.26 & 3.841 \\
DEN & 30.05 & 15.27 & 4.28 & 0.937 & 14.78 & 10.99 & 3.344 & 0.937 \\
HUN & $47.43^{*}$ & 21.60 & 8.847 & 0.818 & $25.83^{*}$ & 12.75 & 8.030 & 0.818 \\
ISL & 34.07 & 18.40 & 6.008 & 0.001 & 15.67 & 12.39 & 6.008 & 0.001 \\
JPN & 34.09 & 16.21 & 4.590 & 0.036 & 17.87 & 11.62 & 4.554 & 0.036 \\
KOR & 38.34 & 15.74 & 6.464 & 0.703 & 22.60 & 9.276 & 5.761 & 0.703 \\
MEX & $55.90^{* * *}$ & $28.77^{*}$ & 11.59 & 1.609 & $27.13^{*}$ & 17.18 & 9.982 & 1.609 \\
NOR & 27.31 & 14.05 & 4.403 & 0.963 & 13.26 & 9.651 & 3.440 & 0.963 \\
NZL & 32.12 & 17.97 & 6.125 & 0.433 & 19.19 & 12.57 & 4.969 & 0.510 \\
POL & $49.22^{* *}$ & 24.40 & 7.687 & 1.006 & 24.81 & 16.71 & 6.682 & 1.006 \\
SWE & 26.54 & 13.91 & 5.577 & 0.900 & 12.63 & 8.337 & 4.677 & 0.900 \\
CHE & 28.77 & 14.29 & 4.073 & 0.232 & 14.48 & 10.21 & 3.840 & 0.232 \\
TUR & $68.83^{* * *}$ & $28.53^{*}$ & 12.98 & 1.392 & $40.30^{* * *}$ & 15.55 & 11.59 & 1.392 \\
UK & 37.12 & 18.72 & 5.933 & 0.086 & 18.40 & 12.79 & 5.847 & 0.086 \\
\hline
\end{tabular}

1052

Notes: This table provides the statistics of cointegration tests. The number of cointegrating vectors is denoted by $r$. Asterisks *,** and *** denote rejections of null hypothesis at $10 \%, 5 \%$ and $1 \%$ significance levels, respectively.

1055

1056

1057

1058

1059

1060

1061

1062

1063

1064

1065

1066

1067 
Table 5 Results of asymmetry test

\begin{tabular}{ccc}
\hline & Mork's asymmetry test & Hamilton's asymmetry test \\
\hline AUS & $3.063[0.801]$ & $5.957[0.428]$ \\
CAN & $6.160[0.406]$ & $2.960[0.814]$ \\
CHE & $4.967[0.548]$ & $5.138[0.526]$ \\
CZE & $20.47 * * *[0.002]$ & $13.34 * *[0.038]$ \\
DEN & $2.991[0.810]$ & $4.953[0.550]$ \\
HUN & $2.703[0.845]$ & $2.194[0.901]$ \\
ISL & $7.119[0.310]$ & $17.80 * *[0.042]$ \\
JPN & $7.028[0.328]$ & $3.706[0.716]$ \\
KOR & $6.137[0.408]$ & $3.881[0.693]$ \\
MEX & $4.783[0.572]$ & $5.315[0.504]$ \\
NOR & $3.761[0.709]$ & $7.651[0.265]$ \\
NZL & $3.312[0.769]$ & $5.189[0.520]$ \\
POL & $3.519[0.741]$ & $2.657[0.851]$ \\
TUR & $4.719[0.580]$ & $3.490[0.745]$ \\
SWE & $1.875[0.931]$ & $4.548[0.603]$ \\
UK & $4.012[0.675]$ & $5.803[0.446]$ \\
\hline
\end{tabular}

1077

1078

1079

1080

1081

1082

1083

1084

1085

1086

1087

1088

1089

1090

1091

Notes: This table reports the results of asymmetry test. The null hypothesis of symmetric effect of changes in oil price change on real exchange rate is to be tested based on model specification $\Delta e r_{t}=c+\sum_{i=1}^{j} \boldsymbol{\beta}^{\prime} \mathbf{y}_{t-i}+\sum_{i=1}^{j} \gamma_{i} \Delta o p_{t-i}^{\#}+\varepsilon_{t}$, where the lag length $\mathrm{j}=6$. The null hypothesis can be written as $H_{0}: \gamma_{1}=\gamma_{2}=\ldots=\gamma_{6}=0$. The chi-square statistics with degree of freedom of 6 and its p-values are given in squared parentheses. Asterisk * denotes significance at $10 \%$ level. 
Table 6 Results of nonlinear causality test

\begin{tabular}{cllllll}
\hline & $l_{x}=l_{y}=1$ & $l_{x}=l_{y}=2$ & $l_{x}=l_{y}=3$ & $l_{x}=l_{y}=4$ & $l_{x}=l_{y}=5$ & $l_{x}=l_{y}=6$ \\
\hline AUS & 0.142 & 0.164 & 0.265 & 0.409 & 0.472 & 0.552 \\
CAN & 0.209 & 0.258 & 0.153 & 0.121 & 0.201 & 0.426 \\
CHE & 0.408 & 0.286 & 0.418 & 0.709 & 0.613 & 0.523 \\
CZE & $0.030^{* *}$ & $0.021^{* *}$ & $0.071^{*}$ & 0.137 & 0.168 & $0.099^{*}$ \\
DEN & 0.239 & 0.507 & 0.588 & 0.714 & 0.746 & 0.623 \\
HUN & $0.072^{*}$ & $0.095^{*}$ & 0.306 & 0.584 & 0.710 & 0.805 \\
ISL & 0.262 & 0.445 & 0.502 & 0.511 & 0.785 & 0.799 \\
JPN & 0.307 & 0.262 & 0.217 & 0.551 & 0.371 & $0.053^{*}$ \\
KOR & 0.168 & 0.390 & 0.388 & 0.562 & 0.585 & 0.470 \\
MEX & 0.673 & 0.732 & 0.794 & 0.677 & 0.873 & 0.756 \\
NOR & 0.457 & 0.406 & 0.785 & 0.905 & 0.965 & 0.891 \\
NZL & 0.291 & 0.365 & 0.688 & 0.537 & 0.496 & 0.502 \\
POL & 0.212 & 0.260 & 0.335 & 0.653 & 0.739 & 0.814 \\
TUR & 0.219 & $0.022^{* *}$ & $0.065^{*}$ & 0.186 & 0.318 & 0.411 \\
SWE & 0.338 & 0.208 & 0.228 & 0.451 & 0.548 & 0.333 \\
UK & 0.380 & 0.647 & 0.520 & 0.749 & 0.856 & 0.453 \\
\hline
\end{tabular}

Notes: This table provides the p-values for Diks and Panchenko's nonlinear causality test for the null hypothesis that oil prices cannot Granger cause exchange rates. Following the suggestion of Diks and Panchenko, we use a right-tailed test. The asterisks *,** and $* * *$ denote rejections of null hypothesis at $10 \%, 5 \%$ and $1 \%$ significance levels, respectively.

1105

1106 